\title{
The Rx Gene Confers Resistance to a Range of Potexviruses in Transgenic Nicotiana Plants
}

\author{
Isabelle Baurès, ${ }^{1}$ Thierry Candresse, ${ }^{2}$ Aymeric Leveau, ${ }^{1}$ Abdelhafid Bendahmane, ${ }^{1}$ and \\ Bénédicte Sturbois ${ }^{1}$ \\ ${ }^{1}$ INRA-URGV and Université Evry Val d'Essonne 2 rue Gaston Crémieux CP 570891057 EVRY Cedex, France; équipe \\ de Virologie, UMR GDPP, INRA and Université Victor Ségalen Bordeaux 2, IBMV, Campus INRA, BP81, 33883 Villenave \\ d'Ornon Cedex, France
}

Submitted 12 December 2007. Accepted 11 April 2008.

\begin{abstract}
$R x$-mediated resistance was analyzed in $R x$-expressing transgenic Nicotiana plants. The infection outcome of nine Potato virus $X$ isolates mutated at amino acid positions 121 and 127 of the coat protein $(\mathrm{CP})$ confirmed the key role of these amino acids but provided a more complex picture than previously reported. In particular, in $R x$-expressing Nicotiana spp., eliciting activity modulated by amino acid 121 was conditioned by the nature of amino acid 127 . These results suggest that the specificity of recognition might be modulated by host factors that are somehow subtly modified between $R x$-expressing potato and $R x$-expressing transgenic Nicotiana plants. Moreover, the $\mathrm{CP}$ of three Potexviruses, Narcissus mosaic virus (NMV), White clover mosaic virus (WCIMV), and Cymbidium mosaic virus (CymMV), are all recognized by the $R x$-based machinery and able to trigger an $\boldsymbol{R} \boldsymbol{x}$-dependant hypersensitive response. A smaller elicitor of 90 amino acids was identified in the CP of NMV and WCIMV, which contains the previously identified key positions 121 and 127. This elicitor is only weakly conserved (approximately $40 \%$ identity) among the $\mathrm{CP}$ of the various recognized viruses, suggesting that the $R x$ molecular machinery targets a conserved structural element of the Potexvirus $\mathbf{C P}$ rather than a conserved amino acid motif.
\end{abstract}

Additional keywords: extreme resistance, hypersensitive response.

Plant disease resistance can be mediated by a multilayered innate immune system which, in some aspects, shows similar features within animal immunity (Numberger et al. 2004). The first layer in this process is referred to as pathogen-associated molecular pattern (PAMP)-triggered immunity (PTI) (Jones and Dangl 2006). PTI consists of recognition of conserved PAMPs followed by the induction of basal defenses. The second layer is referred to as effector-triggered immunity (ETI). ETI involves recognition by plant disease resistance (R) proteins of specific avirulence effectors (Avr) produced by the pathogen. This interaction is known as pathogen race-host plant cultivar-specific resistance and was first described genetically as the gene-for-gene interaction (Flor 1971). Any protein component of a virus (replicase, coat protein, or move-

Corresponding author: A. Bendahmane; Telephone: +33(0)160 8745 02; Fax: +33(0)160 8745 10; E-mail: bendahm@evry.inra.fr

* The $\boldsymbol{e}$-Xtra logo stands for "electronic extra" and indicates that one supplementary table and five supplementary figures are published online. ment protein) can function as the specific Avr determinant to elicit resistance mediated by a given $R$ gene (Martin et al. 2003). It has been shown that a large subset of $R$ genes, known as the nucleotide binding site leucine-rich repeat (NBS-LRR) resistance genes, can be implicated in this type of immunity (Jones and Dangl 2006). Despite the availability of several cloned $R$ genes and their cognate $A v r$ determinants, progress have been slow in the characterization of Avr determinants and in understanding how pathogen Avr proteins are recognized.

It is generally understood that $\mathrm{R}$ proteins directly or indirectly recognize an Avr elicitor (Dangl and Jones 2001) to trigger signal transduction cascades leading to defense and disease resistance. These responses are generally associated with a type of programmed cell death termed the hypersensitive response (HR) (Heath 2000; Shirasu and Schulze-Lefert 2000).

The genetically dominant $R x$ gene encodes a member of the NBS-LRR family of $\mathrm{R}$ proteins conferring race-specific resistance against Potato virus $X$ (PVX, Potexvirus) (Cockeram 1970). This resistance can be described in terms of an elicitorreceptor model. Among the $\mathrm{R}$ proteins, the phenotype of resistance by $R x$ is unusual and is described as extreme resistance (ER) (Bendahmane et al. 1999; Kohm et al. 1993; Tozzini et al. 1991). After inoculation of $R x$-expressing plants with an avirulent PVX isolate (such as $\mathrm{PVX}_{\mathrm{CP} 4}$ ), resistance is induced very early and involves the arrest of PVX accumulation without development of HR. As a consequence, the detection of PVX is almost impossible in inoculated leaves (Bendahmane et al. 1999, 2000; Hajimorad and Hill 2001). Moreover, experiments in potato protoplasts indicated that $R x$ can be active at a single cell level and that a nonspecific response restricts virus accumulation (Kohm et al. 1993). However, in transient expression experiments, $R x$ is able to trigger an HR reaction showing that, under these specific conditions, the nonspecific antiviral response is epistatic over the HR.

The NBS-LRR proteins form the largest class of plant resistance proteins and contain a coiled-coil (CC) domain at the $\mathrm{N}$ terminus, an NBS domain, and an LRR domain at the C-terminus (Ellis et al. 2000; Jones and Jones 1997; Young 2000). The $\mathrm{C}$-terminus of the NBS is referred to as the ARC domain because of its presence in Apaf-1, R proteins, and CED-4 (Aravind et al. 2004; Leipe et al. 2004; Van der Biezen and Jones 1998). The NB-ARC central domain of these proteins has an N-terminal subdomain with a consensus kinase P-loop domain. This domain has been shown, in vitro, to bind and hydrolyze ATP in the case of $I-2$ and $M i-1$ tomato genes. However, it is assumed that the NBS domain acts as a nucleotide-dependent molecular switch which can regulate the conformation and, subsequently, the signaling potential of the proteins of this family (Takken et 
al. 2006; Tameling et al. 2002). The LRR domain, specifically the C-terminal region, is implicated in the recognition of nonself molecules which, in plants, can be direct or indirect (De Young and Innes 2006). Genetic studies have shown that the LRR domain can recognize specific elicitors in both Arabidopsis thaliana (Bittner-Eddy et al. 2000; Botella et al. 1998; McDowell et al. 1998; Noel et al. 1999) and lettuce (Meyers et al. 1998)

Recently, a model for $\mathrm{R}$ protein activation was proposed based on the nucleotide status and intramolecular interactions within the R protein (Moffett et al. 2002; Tameling et al. 2002, 2006). In this model, two different states of the R protein (inactivated and activated) are differentiated by intramolecular interactions between protein domains as well as ADP/ATP binding status. When the NB-ARC domain interacts with both $\mathrm{CC}$ and LRR domains in the presence of ADP, the R protein is inactivated. Recognition of an elicitor initiates a series of conformational changes involving, first, the dissociation of the LRR from the CC-NB-ARC part of the protein with the concomitant release of ADP and, second, dissociation of the interactions between the CC and NB-ARC domain and the binding of ATP. Consequently, the $\mathrm{R}$ protein is activated and can initiate cellular signaling leading to disease resistance (Moffett et al. 2002; Tameling et al. 2006).

Transient expression and reverse genetic experiments have shown that the coat protein $(\mathrm{CP})$ of PVX is the sole elicitor recognized by the product of the $R x$ gene (Bendahmane et al. 1995; Goulden et al. 1993; Kavanagh et al. 1992; Kohm et al. 1993).

According to the general $\mathrm{R}$ model, recognition and response stage are separated in the PVX-Rx system (Bendahmane et al. 1999; Staskawicz et al. 1995). The recognition stage involves (either direct or indirect) interaction between the product of the $R x$ gene and the PVX CP (Bendahmane et al. 1995; Kohm et al. 1993). This stage involves a high degree of specificity, in contrast to the response phase, which is not virus specific (Bendahmane et al. 1999). $R x$-mediated resistance is highly effective not only in the degree of resistance afforded but also in the specificity of the resistance. Indeed, to date, only a single isolate described, $\mathrm{PVX}_{\mathrm{HB}}$, is able to overcome the $R x$-mediated resistance (Moreira et al. 1980; Querci et al. 1993). Mutational analysis of $\mathrm{CP}$ has revealed a major role of the conserved threonine at position 121 of the $\mathrm{CP}$ in avirulence toward $R x$. Substitution of a lysine $(\mathrm{T} 121 \mathrm{~K})$ as observed in $\mathrm{PVX}_{\mathrm{HB}}$ completely abolishes recognition by potato genotypes carrying $R x$ (Goulden et al. 1993). However, PVX isolates containing this $\mathrm{T} 121 \mathrm{~K}$ mutation alone are severely affected not only in their infectivity but also in their ability to systemically invade susceptible hosts (Goulden et al. 1993). A second mutation, R127K, also observed in $\mathrm{PVX}_{\mathrm{HB}}$, contributes to the restoration of the fitness of T121K variants (Goulden et al. 1993).

The recognition stage can involve direct contacts between the elicitor and the $\mathrm{R}$ protein, as with the $N$ gene and the $T o$ bacco mosaic virus p50 helicase (Ueda et al. 2006) or indirect interactions involving other host proteins, as observed with bacterial resistance genes (Belkhadir et al. 2004; Mackey et al. 2003; Van der Biezen and Jones 1998). Recognition via indirect interactions can be explained by way of the guard hypothesis model (Jones and Dangl 2006; Van der Biezen and Jones 1998).

The guard hypothesis model has been proposed for the recognition stage in the PVX-Rx system (Farnham and Baulcombe 2006). Recently, a protein, RanGAP2, has been shown to interact with the $\mathrm{CC}$ domain of $\mathrm{Rx}$ protein (Tameling and Baulcombe 2007). RanGAP2 has also been shown to associate with close homologs of Rx such as Rx2 and Gpa2 (Sacco et al. 2007). Based on the guard model, it can be hypothesized that
$\mathrm{Rx}$ is part of a protein complex that includes RanGAP2 as a virulence target of the PVX CP. However, evidence of a direct physical interaction between RanGAP2 and PVX CP is lacking.

In an effort to understand the detailed mechanisms of Rxmediated resistance, interactions between the $\mathrm{CP}$ elicitor and the Rx protein were investigated using two different approaches.

In the first approach, a series of mutations at the previously identified essential T121 and K127 residues were generated. Analysis of the resultant Rx-mediated resistance was performed in $R x$-expressing transgenic Nicotiana plants. The results show that the biochemical nature of the amino acids at these key positions is able to modulate the specificity of $\mathrm{CP}$ recognition. It seems also that various host factors are able to modulate this recognition stage.

In the second approach, the ability of $R x$-mediated resistance to be triggered by the $\mathrm{CP}$ of other filamentous viruses was investigated. The results show that, in addition to PVX, the $R x$-based sensing mechanism can recognize other Potexviruses, although with different degrees of resistance against these viruses.

\section{RESULTS}

\section{Mutations of the PVX CP influence PVX interaction in $\boldsymbol{R} \boldsymbol{x}$-expressing plants.}

To characterize the interaction between the PVX CP and the $R x$ resistance gene product, the combination of the two key amino acids at positions 121 and 127 of the PVX CP was modified. The avirulent strain $\mathrm{PVX}_{\mathrm{CP} 4}$ and the virulent strain $\mathrm{PVX}_{\mathrm{HB}}$ differ at 79 nucleotide positions, but only 7 differences affect the primary structure of the $\mathrm{CP}$ (Goulden and Baulcombe 1993). $\mathrm{PVX}_{\mathrm{CP} 4}$ and $\mathrm{PVX}_{\mathrm{HB}}$ have a threonine or a lysine in position 121 and a lysine or an arginine in position 127, respectively. Mutations introduced by polymerase chain reaction (PCR) into the $\mathrm{PVX}_{\mathrm{CP} 4}$ cDNA changed the codon at position 121 from a threonine to five other amino acids and the codon at position 127 from a lysine to an arginine. Wild-type (WT) or transgenic $R x$-expressing Nicotiana benthamiana (Bendahmane et al. 1999) were mechanically inoculated with the following transcripts: $\mathrm{PVX}_{\mathrm{CP} 4}, \mathrm{PVX}_{\mathrm{CP} 4-\mathrm{RK}}, \mathrm{PVX}_{\mathrm{CP} 4-\mathrm{VK}}, \mathrm{PVX}_{\mathrm{CP} 4-\mathrm{SK}}$, $\mathrm{PVX}_{\mathrm{CP} 4-\mathrm{PK}}, \quad \mathrm{PVX}_{\mathrm{CP} 4-\mathrm{KK}}, \quad \mathrm{PVX}_{\mathrm{CP} 4-\mathrm{RR}}, \quad \mathrm{PVX}_{\mathrm{CP} 4-\mathrm{VR}}, \quad \mathrm{PVX}_{\mathrm{CP} 4-\mathrm{SR}}$ $\mathrm{PVX}_{\mathrm{CP} 4-\mathrm{PR}}$, and $\mathrm{PVX}_{\mathrm{HB}}$. Symptoms were observed 15 days after inoculation. As shown by reverse-transcription (RT)-PCR and Western blot analysis, the accumulation of the different PVX strains was comparable in WT $N$. benthamiana leaves (Fig. 1; Supplementary Fig. 1).

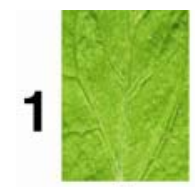

a

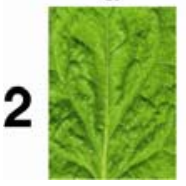

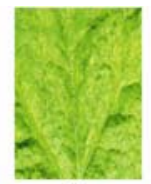

b

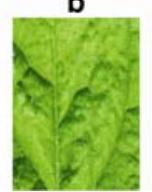

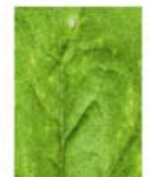

C

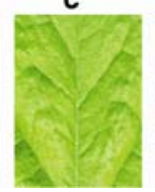

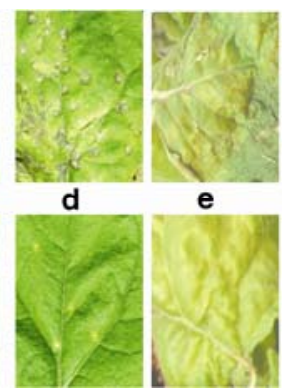

Fig. 1. Effects of mutations of the Potato virus $X$ (PVX) coat protein $(\mathrm{CP})$ on the infection phenotype in transgenic $R x$-expressing Nicotiana benthamiana. Symptoms were observed 15 days postinoculation. 1, Inoculated leaf of $R x$-expressing $N$. benthamiana. 2, Systemic leaf of $R x$-expressing $N$. benthamiana. The two letters indicate the nature of residues 121 and 127 in the PVX CP. The mutant constructs were classified based on the $\mathrm{RX}$-mediated response observed from a to e. a, $\mathrm{PVX}_{\mathrm{CP} 4} ; \mathbf{b}, \mathrm{PVX}_{\mathrm{CP} 4-\mathrm{SK}}$, $\mathrm{PVX}_{\mathrm{CP} 4-\mathrm{VK}}, \mathrm{PVX}_{\mathrm{CP} 4-\mathrm{RK}}, \mathrm{PVX}_{\mathrm{CP} 4-\mathrm{KK}}, \mathrm{PVX}_{\mathrm{CP} 4-\mathrm{PK}}, \mathrm{PVX}_{\mathrm{CP} 4-\mathrm{VR}}$, and $\mathrm{PVX}_{\mathrm{CP} 4-}$ ${ }_{\mathrm{SR}} ; \mathbf{c}, \mathrm{PVX}_{\mathrm{CP} 4-\mathrm{RR}} ; \mathbf{d}, \mathrm{PVX}_{\mathrm{CP} 4-\mathrm{PR}} ; \mathbf{e}, \mathrm{PVX}_{\mathrm{HB}}$. 
As expected, the two parental isolates $\mathrm{PVX}_{\mathrm{CP} 4}$ and $\mathrm{PVX}_{\mathrm{HB}}$ were able to accumulate and spread in WT plants. In the $R x$ expressing plants, $\mathrm{PVX}_{\mathrm{CP} 4}$ induced extreme resistance such that no symptoms were observed on inoculated leaves (Fig. 11a). In addition, no viral accumulation could be detected in either inoculated or noninoculated leaves (data not shown). In parallel, $\mathrm{PVX}_{\mathrm{HB}}$ induced systemic necrosis in the $R x$-expressing plants (Fig. 1-1e), and virus could be detected in both inoculated and noninoculated leaves (data not shown). These results show that $\mathrm{PVX}_{\mathrm{HB}}$ replication as well as cell-to-cell and long-distance movements are permitted in the $R x$-expressing plants (Fig. 1-1e), therefore suggesting that the resistancebreaking status of this strain, observed in potato, is not as complete as in Nicotiana spp.

Following inoculation with PVX CP mutants, three types of interaction phenotypes were observed. The first type of interaction, represented by seven mutants $\left(\mathrm{PVX}_{\mathrm{CP} 4-\mathrm{SK}}, \mathrm{PVX}_{\mathrm{CP} 4-\mathrm{VK}}\right.$, $\mathrm{PVX}_{\mathrm{CP} 4-\mathrm{RK}}, \mathrm{PVX}_{\mathrm{CP} 4-\mathrm{KK}}, \mathrm{PVX}_{\mathrm{CP} 4-\mathrm{PK}}, \mathrm{PVX}_{\mathrm{CP} 4-\mathrm{VR}}$, and $\left.\mathrm{PVX}_{\mathrm{CP} 4-\mathrm{SR}}\right)$, allows accumulation and spreading of the virus in WT plants. However, in $R x$-expressing plants, no symptoms were observed (Fig. 1b) and virus did not detectably accumulate (data not shown). The second type of interaction is represented by the mutant $\mathrm{PVX}_{\mathrm{CP} 4-\mathrm{RR}}$, which also was able to accumulate and spread normally in WT plants. It induced necrotic local lesions on inoculated leaves of $R x$-expressing transgenic plants (Fig. 1-1c) but was unable to accumulate in the noninoculated leaves of these plants (Fig. 1-2c). The final type of interaction is represented by the mutant $\mathrm{PVX}_{\mathrm{CP} 4-\mathrm{PR}}$. Again, accumulation and spreading of the virus occurred in WT plants; however, in $R x$-expressing $N$. benthamiana plants, $\mathrm{PVX}_{\mathrm{CP} 4-\mathrm{PR}^{-} \text {-induced }}$ necrotic local lesions on inoculated leaves were observed (Fig. 1-1d), as well as necrotic lesions on noninoculated leaves (Fig. $1-2 d)$. These results demonstrate that the virus was able to spread from the inoculated leaves to the entire plant.

Sequencing of the entire CP open reading frame of progeny viruses following infection confirmed the stability of introduced mutations (data not shown).

\section{Three other Potexviruses are recognized by $R x$-mediated resistance.}

To test whether the resistance gene $R x$ could also mediate the recognition of other viruses more or less distantly related to PVX, different viruses from the Flexiviridae family, Narcissus mosaic virus (NMV), White clover mosaic virus (WClMV), and Cymbidium mosaic virus (CymMV) in the genus Potexvirus and Helenium virus $S$ (HVS) in the genus Carlavirus, were selected and used to inoculate WT or $R x$-expressing $N$. benthamiana plants. The different viruses were selected based on their ability to systemically infect and induce symptoms in WT N. bentha-

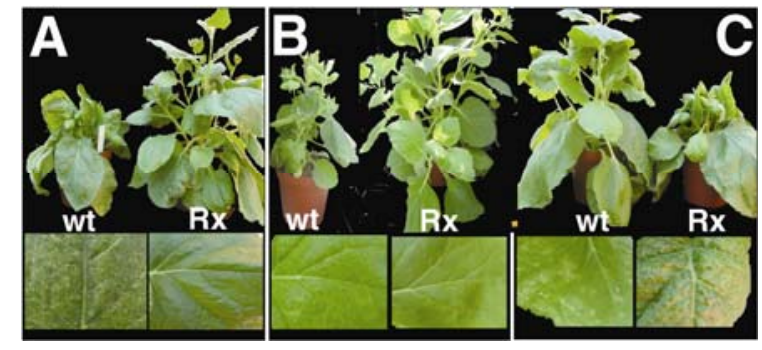

Fig. 2. Symptoms induced after inoculation with various Potexviruses on Nicotiana benthamiana plants. Wild-type (wt; left) and $R x$-expressing (right) N. benthamiana plants were inoculated with $\mathbf{A}$, White clover mosaic virus; $\mathbf{B}$, Narcissus mosaic virus, and $\mathbf{C}$, Cymbidium mosaic virus. Magnification of WT and Rx-expressing $N$. benthamiana leaves showing specific symptoms are also presented. Pictures were taken 21 days after inoculation. miana control plants (Fig. 2; Supplementary Fig. 2). Phenotypes were observed 21 days after inoculation.

Four different phenotypes were observed in $R x$-expressing $N$. benthamiana plants. Inoculation with HVS induced mosaic symptoms. Inoculation with $\mathrm{PVX}_{\mathrm{HB}}$ resulted in systemic necrosis. No symptoms were observed following inoculation with NMV, WCIMV (Fig. 2A and $\mathrm{B}$ ), or $\mathrm{PVX}_{\mathrm{CP} 4}$ representing a third phenotype. Transcript levels of NMV and WCIMV were determined by RT-PCR in both inoculated and systemic leaves of the WT plants. However, no CP coding region could be detected in leaves of $R x$-expressing plants (Fig. 3), confirming absence of accumulation and movement of WCIMV and NMV viruses in these plants. The fourth phenotype was observed in $R x$-expressing plants inoculated with CymMV, where a pronounced mottling and stunted phenotype was seen (Fig. 2C). Accumulation and spread of CymMV in the WT and $R x$ expressing plants was confirmed by RT-PCR analysis of CP expression (Fig. 3).

These results show that, for the three Potexviruses tested (NMV, WCIMV, and CymMV), differences in infection phenotypes were observed between WT and $R x$-expressing plants (Fig. 2). In contrast, these differences were not observed with the Carlavirus, HVS, suggesting that these three Potexviruses, and not the Carlavirus, are specifically affected by $R x$-mediated resistance mechanisms. To evaluate this hypothesis, we then assayed the ability of the $\mathrm{CP}$ of these viruses to specifically induce an HR when transiently expressed in leaves of $R x$ expressing plants.

\section{The CP of NMV, WCIMV, and CymMV elicit an $R x$-mediated HR.}

The CP of two parental PVX isolates, the three other Potexviruses (NMV, WClMV, and CymMV), and the Carlavirus (HVS) were cloned in an Agrobacterium binary vector and transiently expressed, by agroinfiltration, in WT and $R x$ expressing $N$. tabacum leaves which are more resistant to multiple agroinfiltrations.

In contrast, on WT plants, no HR was induced following infiltration (Fig. 4). In $R x$-expressing plants, an HR was observed
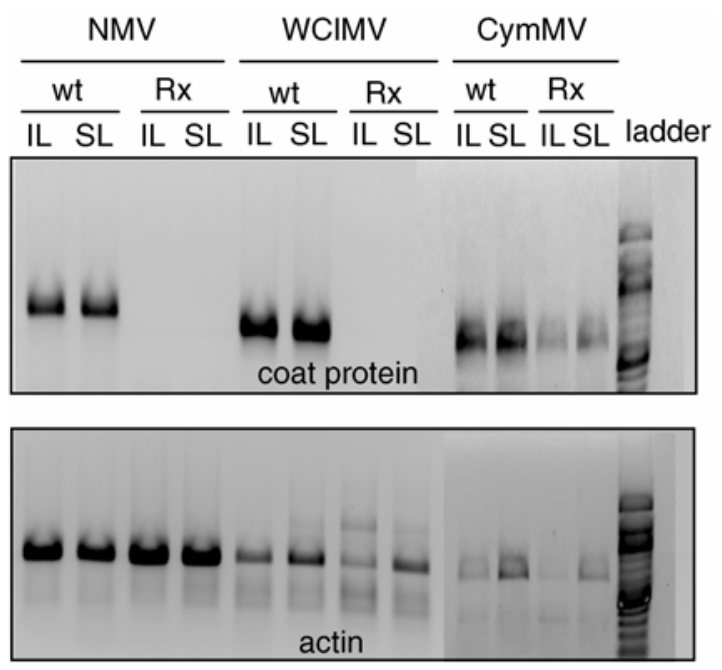

Fig. 3. Accumulation of the various Potexviruses in Nicotiana benthamiana as revealed by reverse-transcription polymerase chain reaction analysis (RT-PCR). The amplified products corresponding to the sequence of complete open reading frames (ORFs) of the coat protein of Narcissus mosaic virus (NMV), White clover mosaic virus (WCIMV), Cymbidium mosaic virus (CymMV), and to actin ORF are indicated. Total RNA extracted from tissue of inoculated leaves (IL) and systemic leaves (SL) 21 days after inoculation of wild-type (wt) or $R x$-expressing tobacco was used for RT-PCR analysis. 

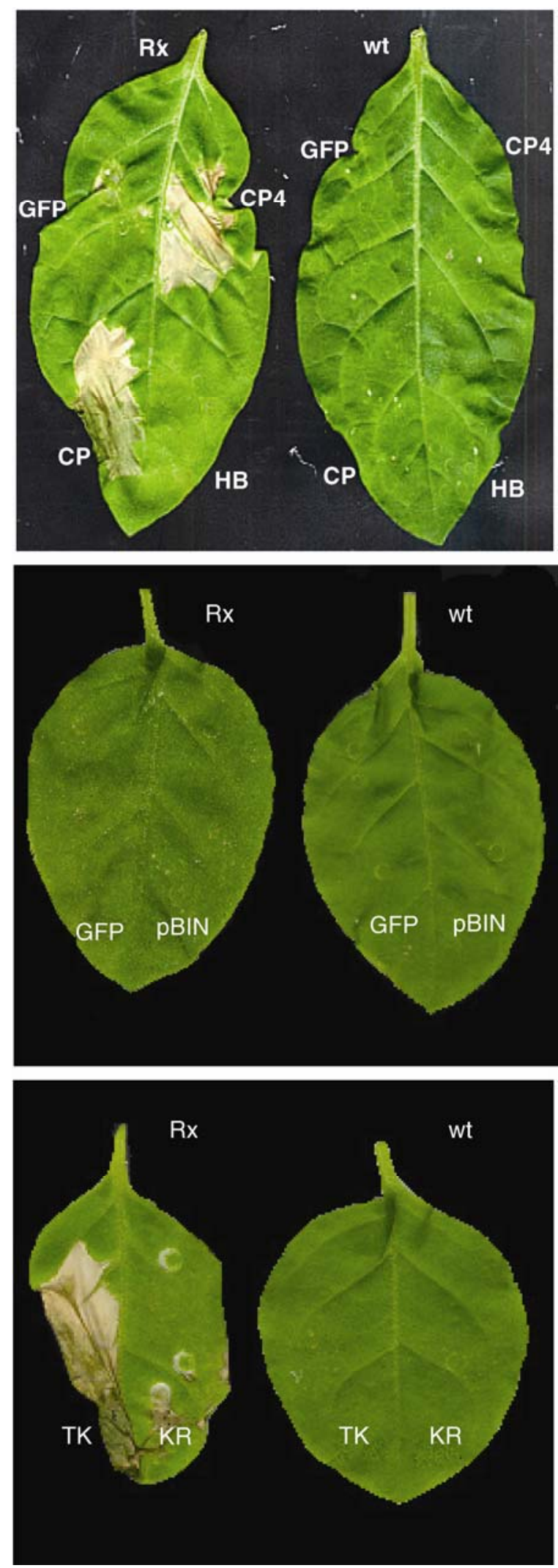

Fig. 4. Hypersensitive reaction observed in wild type (wt) and $R x$-expressing (Rx) Nicotiana tabacum leaves following agroinfiltration with Agrobacteria harboring constructs allowing the transient expression of the complete White clover mosaic virus (WClMV) coat protein (CP). Abbreviations indicate Agrobacteria culture carrying: $\mathrm{CP} 4=$ complete $\mathrm{CP}$ open reading frame (ORF) of Potato virus $X(\mathrm{PVX})_{\mathrm{CP} 4}, \mathrm{CP}=$ construct with complete $\mathrm{CP} \mathrm{ORF}$ of WCIMV, $\mathrm{HB}=$ complete $\mathrm{CP}$ ORF of $\mathrm{PVX}_{\mathrm{HB}}, \mathrm{GFP}=$ complete $\mathrm{ORF}$ of green fluorescent protein, and pBIN61 = empty pBIN 61 vector. Pictures were taken 6 days after infiltration. following expression of $\mathrm{PVX}_{\mathrm{CP} 4} \mathrm{CP}$ but not of $\mathrm{PVX}_{\mathrm{HB}} \mathrm{CP}$ (Fig. 4). Infiltration of agrobacteria containing the empty vector did not induce an HR (Fig. 4).

A necrotic reaction similar to the one induced by the $\mathrm{CP}$ of PVX $_{\mathrm{CP} 4}$ was observed 6 days after infiltration by the WCIMV CP (Fig. 4), NMV CP, and CymMV CP. No reaction was observed following transient expression of HVS CP (Supplementary Fig. 3). These results show that the sensing system mediated by the $R x$ gene is able to recognize the CP of these three other Potexviruses and to trigger an HR.

Identification of a smaller elicitor of $\boldsymbol{R} \boldsymbol{x}$-mediated responses.

The domain of PVX able to elicit the $R x$-mediated response was previously shown to be limited to amino acids 30 and 139 of the PVX CP (Bendahmane et al. 1995; Moffet et al. 2002). Therefore, the possibility that a similar domain of three other Potexvirus CP could trigger $R x$-mediated response was investigated.

The region comparable to positions 30 to 139 of PVX CP was determined for the three other viruses (Figs. 5, fragment 7, and 6A; Supplementary Fig. 4) by sequence alignment. Three shorter constructs were also generated for the three Potexvirus $\mathrm{CP}$ (Fig. 6A, fragments 2, 5; and 6) which were truncated at their N-terminus by 20 amino acids or their C-terminus by 12 amino acids. All truncated versions were cloned into the Agrobacterium binary vector and transient expression was performed in WT and $R x$-expressing $N$. tabacum leaves. As expected, no necrotic reaction was observed with any of the constructs in infiltrated leaves of the WT plants (Fig. 6). Construct 1 of the WCIMV CP (corresponding to positions 30 to 139 of the PVX

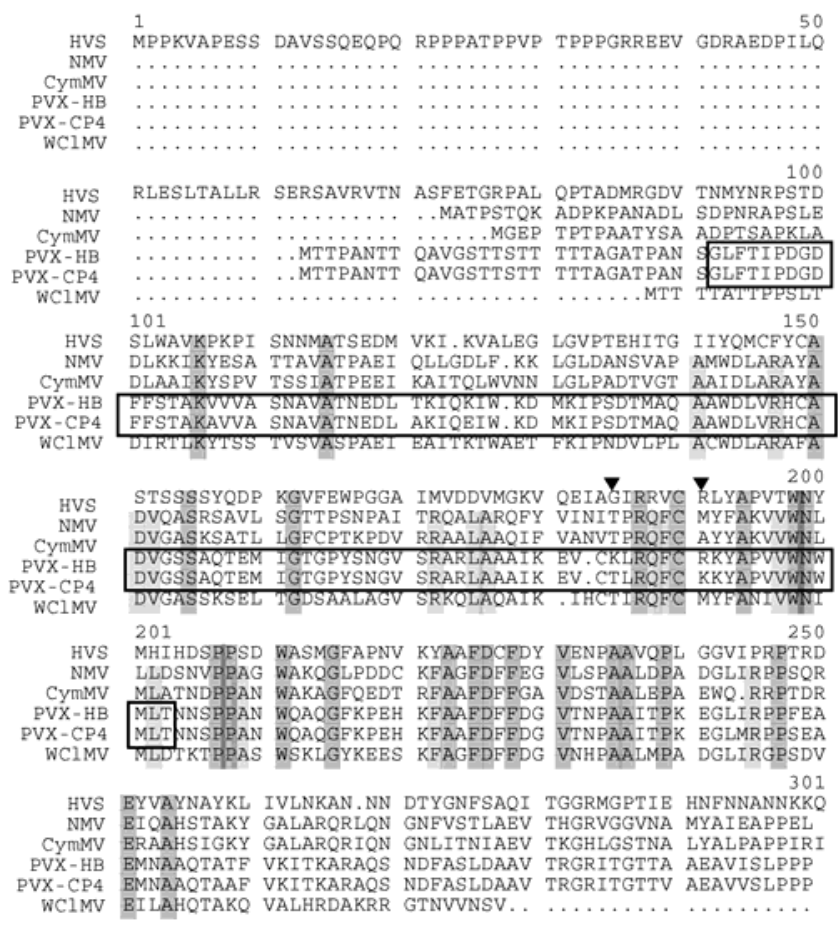

Fig. 5. Multiple alignment of the amino acid sequences of the coat protein (CP) of Narcissus mosaic virus (NMV), White clover mosaic virus (WClMV), Cymbidium mosaic virus (CymMV), and Helenium virus $S$ (HVS) with those of the CP4 and HB strains of Potato virus $X$ (PVX). Published sequences for the two PVX isolates and sequences determined in this work for other viruses were aligned using MultAlin software. The amino acids conserved in all sequences (even in HVS) are highlighted in dark gray; amino acids conserved only in Potexviruses are in gray. The arrowheads indicate key amino acids 121 and 127 . The minimal elicitor of PVX for $R x$-mediated-resistance, described by Bendahmane and associates (1995), is boxed. 
CP) was able to elicit $R x$-mediated HR whereas no necrosis could be observed on the infiltrated WT leaves (Fig. 6B). The same HR was observed after infiltration of construct 6 (corresponding to positions 50 to 139 of the PVX CP) (Fig. 6B). After transient expression of constructs 2 or 5 (corresponding to positions 50 to 127 and 30 to 127 of the PVX CP, respectively), no necrotic reaction was observed (Fig. 6B). As shown in the RT-PCR results (Fig. 6C), the constructs containing the coding sequence of the different fragments of WCIMV $\mathrm{CP}$ agroinfiltrated in WT and $R x$-expressing $N$. tabacum led to the synthesis of the corresponding RNAs in the same quantity. These results suggest that the lack of symptoms on $R x$-expressing leaves, observed for the fragments 2 and 5 of the WCIMV $\mathrm{CP}$ (Fig. 6B), is not due to the absence of the corresponding
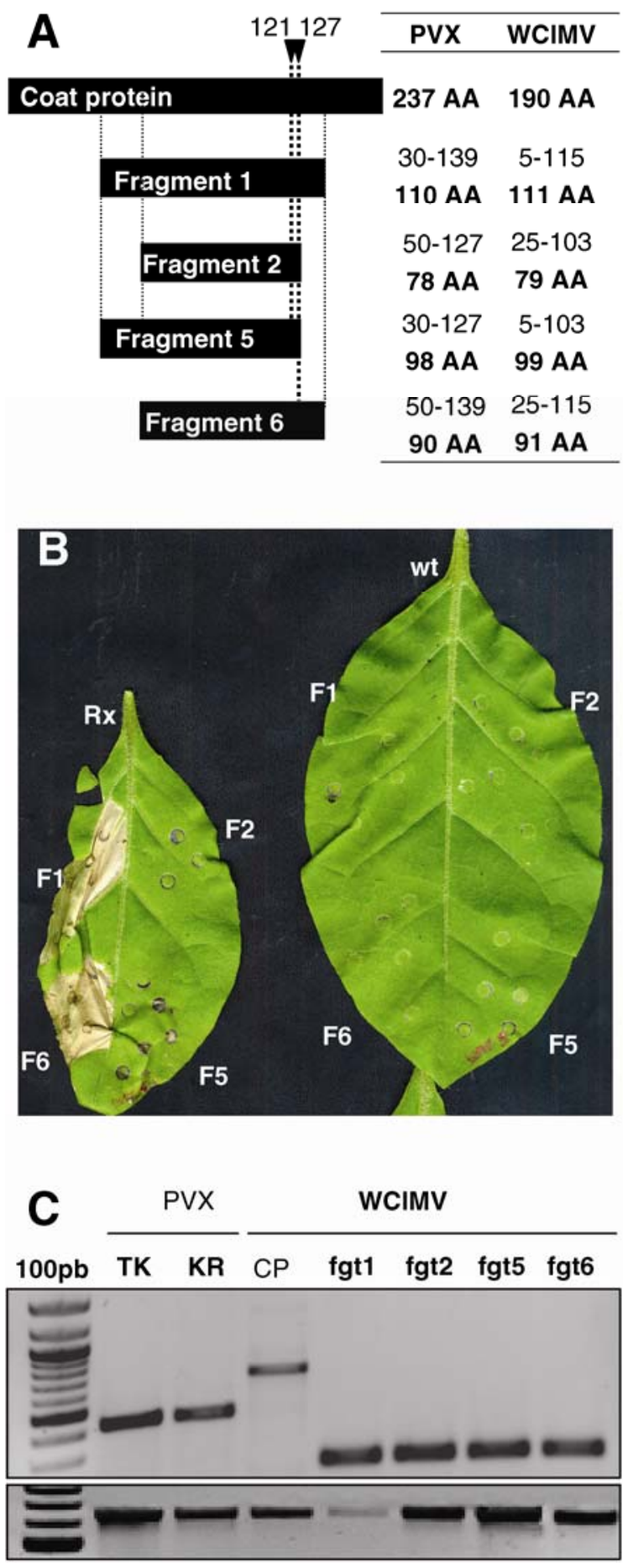

RNA but to the inability of these CP fragments to elicit the $R x$ mediated resistance.

Similar results were observed with the corresponding constructs derived from the CP of NMV (Supplementary Fig. 5); however, no necrotic reaction was observed following infiltration of constructs derived from the CP of CymMV. As expected, construct 1 derived from the HVS CP failed to elicit an HR.

These results demonstrate that, for two Potexviruses (NMV and $\mathrm{WClMV}$ ), the $\mathrm{N}$ - and $\mathrm{C}$-terminal parts of $\mathrm{CP}$ are not required for elicitation of the $R x$-mediated response. Therefore, the size of the minimal region of the $\mathrm{CP}$ essential for elicitation was reduced to a domain of 90 amino acids corresponding to positions 50 to 139 of the PVX CP.

\section{Quantification of elicitor activity induced by the various Potexvirus CP.}

In an effort to characterize the $\mathrm{CP}-R x$ interaction, we quantified and compared the $R x$-mediated $\mathrm{HR}$ in response to the recognized three Potexvirus $\mathrm{CP}$ and the $\mathrm{CP}$ of $\mathrm{PVX}_{\mathrm{CP} 4}$ and $\mathrm{PVX}_{\mathrm{HB}}$ (controls). All CP were transiently expressed in WT or $R x$-expressing $N$. benthamiana leaves and the cell death response was quantified by measurement of electrolyte leakage at 24,48 , and $72 \mathrm{~h}$ after infiltration (Fig. 7).

Expression of the $\mathrm{PVX}_{\mathrm{HB}} \mathrm{CP}$, which is unable to elicit an $\mathrm{HR}$, failed to induce an increase in conductivity after $24 \mathrm{~h}$ but induced a weak electrolyte leakage after 48 and $72 \mathrm{~h}$ (Fig. 7). Similar results have been reported in $N$. benthamiana (Farnham and Baulcombe 2006), where a weak response was observed in WT plants after transient expression of $\mathrm{PVX}_{\mathrm{HB}} \mathrm{CP}$. Moreover, the expression of the $\mathrm{PVX}_{\mathrm{CP} 4} \mathrm{CP}$ induced a strong and lasting increase of conductivity in $R x$-expressing plants, reflecting an $R x$-mediated HR (Fig. 7A). In contrast, expression of HVS CP failed to induce a significant increase in conductivity in $R x$ expressing plants (Fig. 7A). Expression of WCIMV, NMV, and CymMV CP in $R x$-expressing $N$. benthamiana resulted in electrolyte leakage as with $\mathrm{PVX}_{\mathrm{CP} 4}$ (Fig. 7B). However, the magnitude of the reaction with WCIMV seemed to be higher after 24 and $48 \mathrm{~h}$ than with the other $\mathrm{CP}$, then decreased after $72 \mathrm{~h}$. The differences observed with CymMV compared with PVXCP4 were not significant. The absence of any significant electrolyte leakage following infiltration of all CP in WT $N$. benthamiana confirmed that the observed phenotype is $R x$ mediated (Fig. 6B).

Fig. 6. Identification of a smaller elicitor of the $R x$-mediated response. A, Schematic representation of fragments of coat protein (CP). Fragments 1 to 6 of $\mathrm{CP}$ of different viruses are tested for their ability to elicit an $R x$-mediated response. The amino acids encompassed by the different fragments and the overall length are indicated for Potato virus $X$ (PVX) and White clover mosaic virus (WCIMV). B, Hypersensitive reaction observed in wild-type (wt) and $R x$-expressing (Rx) Nicotiana tabacum leaves following agroinfiltration with Agrobacteria harboring constructs allowing the transient expression of the partial WCIMV CP. Abbreviations indicate Agrobacteria culture carrying: F1 = construct with coding sequence for fragment 1 of WCIMV CP, F2 = construct with coding sequence for fragment 2 of WCIMV CP, F5 = construct with coding sequence for fragment 5 of WCIMV CP, and F6 = construct with coding sequence for fragment 6 of WCIMV CP. Pictures were taken 6 days after infiltration. C, Accumulation of the various WCIMV CP fragments as revealed by reverse-transcription polymerase chain reaction (RT-PCR). The amplified products corresponding to the sequence of complete ORF of coat protein of PVX-TK, PVX-KR, WClMV, and fragments 1, 2, 5, and 6 of WCIMV are indicated. Total RNAs extracted from tissue of wt $N$. tabacum leaves harvested 6 days after agroinfiltration were used for RT-PCR analysis. For WCIMV CP fragments, the same oligonucleotides have been used, resulting in the same size product $(273 \mathrm{bp})$. For the complete $\mathrm{CP}$, the expected size is $702 \mathrm{bp}$. The expression of actin has been used as control (bottom panel). 


\section{DISCUSSION}

The PVX CP is known to be the avirulence determinant triggering $R x$-mediated defense response in potato (Kavanagh et al. 1992; Kohm et al. 1993). Mutagenesis of codons 121 or 127 impairs the ability of the virus to accumulate and spread in the infected plant (i.e., viral fitness) (Goulden et al. 1993) but also affects the ability of the $\mathrm{CP}$ to be recognized by the $R x$-sensing

A

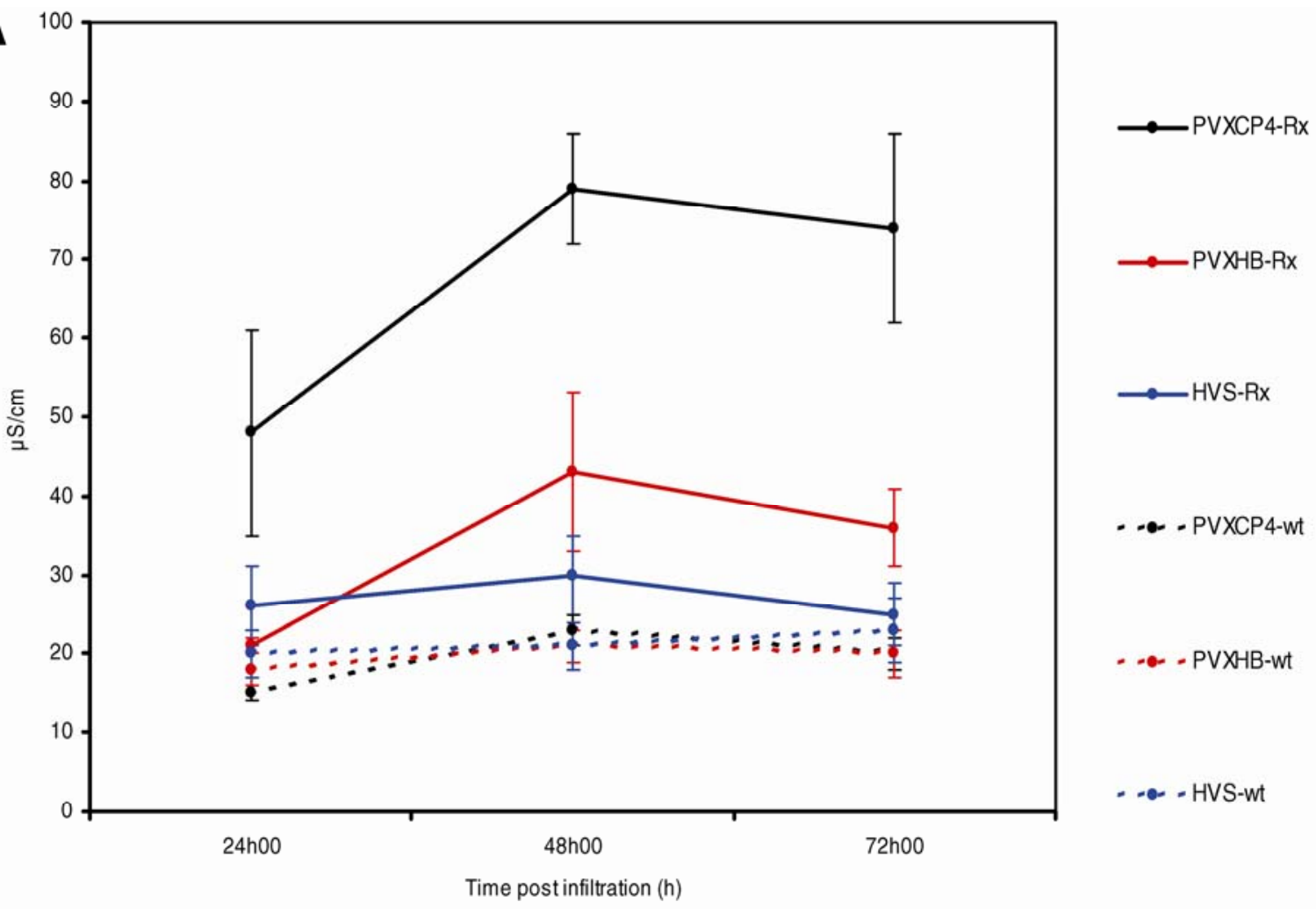

B

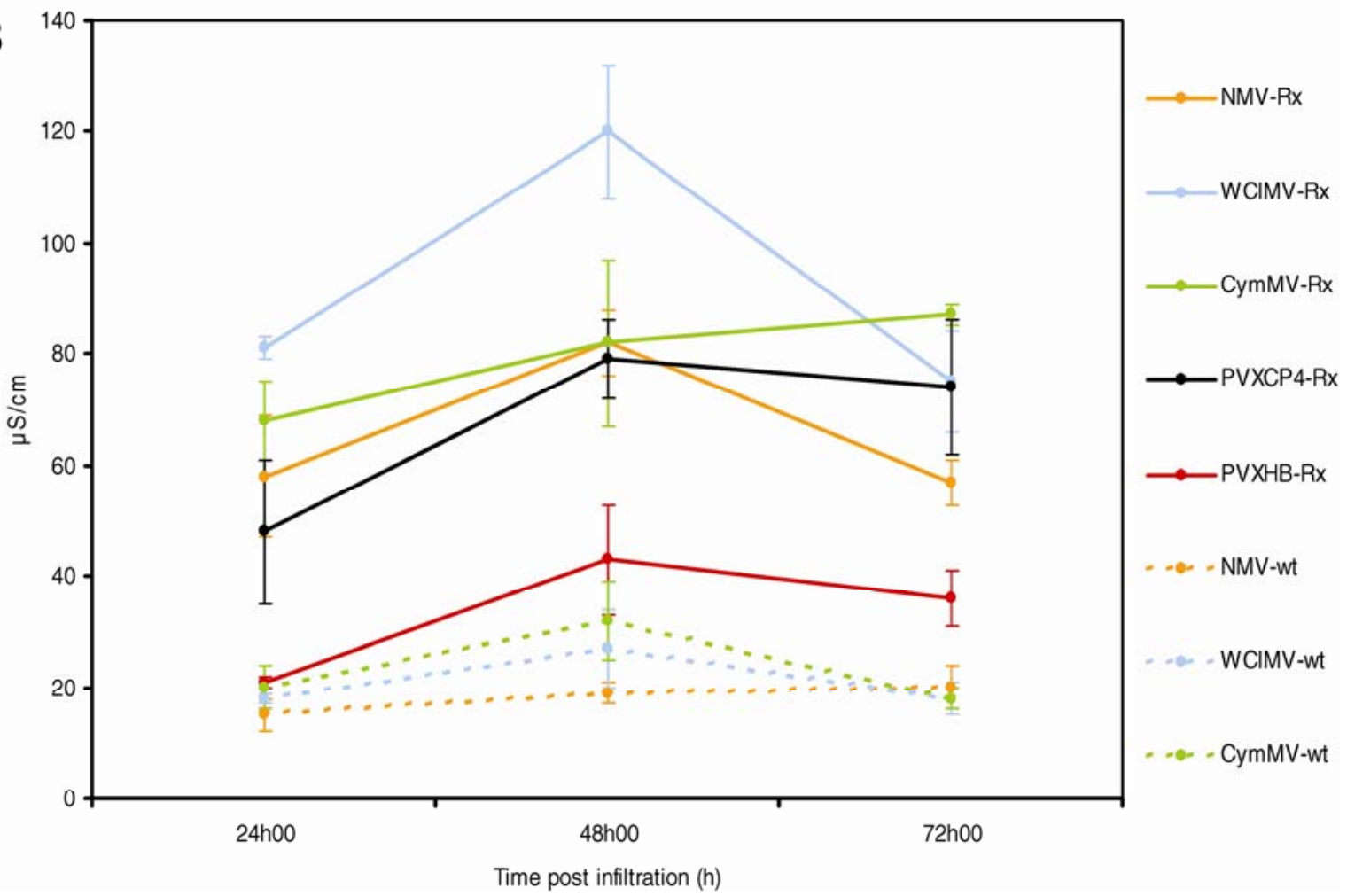

Fig. 7. Conductivity of the intercellular fluid extracted from leaves of wild-type or $R x$-expressing Nicotiana benthamiana plants following infiltration with Agrobacteria carrying constructs allowing the expression of the coat protein (CP) of various potexviruses. Conductivity $\left(\mu \mathrm{S} \mathrm{cm}{ }^{-1}\right) \mathrm{measurements}$ were derived from samples processed at the indicated time (h) after infiltration. Higher conductivity levels are indicative of increased membrane leakage and imminent cell death. A, Expression of the CP of parental viruses and Helenium virus $S$ (HVS) are tested on wild-type (wt) and $R x$-expressing plants. B, Expression of the $\mathrm{CP}$ of other viruses on wt and $R x$-expressing plants compared with results obtained with parental viruses on $R x$-expressing plants. Results are calculated as the mean $\pm \mathrm{SD} . \mathrm{PVX}=$ Potato virus $X, \mathrm{NMV}=$ Narcissus mosaic virus, $\mathrm{WCIMV}=$ White clover mosaic virus, and CymMV $=$ Cymbidium mosaic virus . 
machinery. According to previous studies (Goulden et al. 1993), the resistance is induced in potato only when a threonine residue is present at position 121 of the CP. Interestingly, this threonine residue is conserved in the $\mathrm{CP}$ of all known isolates

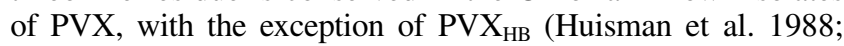
Kavanagh et al. 1992; Orman et al. 1990; Skryabin et al. 1988). In addition, the lysine at position 127 may act as a secondary feature of the avirulence determinant in $R x$-expressing potato (Goulden et al. 1993).

In our experiments using $N$. benthamiana WT plants, all mutations affecting these amino acids showed a strong leaf mosaic phenotype, reflecting the efficient accumulation and spreading of the virus as revealed by RT-PCR and Western blot analysis. This is somewhat surprising in view of the debilitating effects of the $\mathrm{T} 121 \mathrm{~K}$ mutation reported previously (Goulden et al. 1993). This discrepancy may be explained by the previous experiments being performed in potato whereas the experiments reported here were performed in $N$. benthamiana. There are numerous reports describing similar situations in which modified viruses were able to mount a systemic infection in some hosts but not in others, with $N$. benthamiana frequently appearing as a more permissive host (Fujita et al. 2000; Lee et al. 2002; Spetz and Valkonen 2004; Wang et al. 1998). It also appears that the negative effects of the $\mathrm{T} 121 \mathrm{~K}$ mutation on viral systemic movement reported previously (Goulden et al. 1993) are in fact host specific and observed in potato but not in the more permissive $N$. benthamiana.

All PVX strains containing a lysine at position 127 failed to accumulate or induce symptoms in $R x$-expressing $N$. benthamiana (Fig. 1). This result is contrasted by previous experiments which show that, among PVX strains harboring a lysine at position $127, \mathrm{PVX}_{\mathrm{CP} 4-\mathrm{KK}}$ and $\mathrm{PVX}_{\mathrm{CP} 4-\mathrm{RK}}$ were the only ones able to accumulate in $R x$-expressing potato protoplasts (Bendahmane et al. 1995), and that $\mathrm{PVX}_{\mathrm{CP} 4-\mathrm{KK}}$ systemically invades $R x$-expressing potato plants (Goulden et al. 1993). It is difficult to reconcile these previous observations with our results, other than postulating that, particularly in the case of $\mathrm{PVX}_{\mathrm{CP} 4-\mathrm{KK}}$, the specificity of the $R x$-based recognition system is subtly modified between the original $R x$-expressing potato and the $R x$-expressing $N$. benthamiana used in these experiments. As a consequence, it seems that the genetic background in which the resistance gene is expressed could influence the specificity of recognition. Alternatively, it has been shown, for different resistance genes (I gene and $T m$ gene), that virus accumulation observed in protoplasts does not necessarily correlate with results observed at a wholeplant level (Cadle-Davidson and Jahn 2005; Collmer et al. 2000; Fraser and Loughlin 1980; Motoyoshi and Oshima 1977). Taking into consideration the guard hypothesis (Dangl and Jones 2001) of the mode of action of $\mathrm{R}$ proteins, another explanation for the discrepancies could be that, in $R x$-expressing $N$. benthamiana, interaction of the $R$ gene product with Nicotiana orthologs of the potato cellular interactors could somehow modulate the specificity of the $R x$ recognition complex.
The situation is different for the mutants, which possess an arginine at position 127 . Very different infection outcomes were observed, ranging from extreme resistance with $\mathrm{PVX}_{\mathrm{CP} 4}$ SR and $\mathrm{PVX}_{\mathrm{CP} 4-\mathrm{VR}}$ to systemic necrosis with $\mathrm{PVX}_{\mathrm{HB}}$ and two intermediate phenotypes, local lesions without systemic infection for $\mathrm{PVX}_{\mathrm{CP} 4-\mathrm{RR}}$, and an $\mathrm{HR}$ with systemic infection for $\mathrm{PVX}_{\mathrm{CP} 4-\mathrm{PR}}$ (Fig. 1). These different infection phenotypes probably reflect differences in recognition efficiency of the $\mathrm{CP}$ modulated by the amino acid present at position 121. Similar variations in elicitor activity are reported in $R x$-expressing potato protoplasts using $\mathrm{PVX}_{\mathrm{CP}}$-derived mutants (Bendahmane et al. 1995). Despite the fact that no HR was observed upon transient expression of the $\mathrm{PVX}_{\mathrm{HB}} \mathrm{CP}$ in $R x$-expressing leaves (Fig. 4), both the $R x$-dependent systemic infection phenotype of the virus and the weak but significant $R x$-dependant increase in conductivity observed upon $\mathrm{PVX}_{\mathrm{HB}} \mathrm{CP}$ expression (Fig. 7B) indicate that $\mathrm{PVX}_{\mathrm{HB}}$ is not fully avirulent but has a low level of interaction with the $R x$-mediated sensing system in the $R x$-expressing $N$. benthamiana. Weak or absent $R x$-mediated cell death following transient expression of $\mathrm{CP} \mathrm{PVX}_{\mathrm{HB}}$ in $N$. benthamiana has previously been observed (Farnham and Baulcombe 2006).

Taken together, the results reported here reinforce the key role of the amino acids at positions 121 and 127 in the recognition of PVX CP by the product of the $R x$ gene. In contrast to previous results claiming that $\mathrm{T} 121$ has a central role in the recognition process (Goulden et al. 1993), our results suggest an important role for amino acid 127 as well, because all mutants with a lysine at this position were efficiently recognized, regardless of the nature of the amino acid at position 121 (Fig. 1).

Moreover, our results suggest that the recognition stage may be slightly different depending on the genetic background, revealing a more complex structure-function relationship pattern than was previously described (Bendahmane et al. 1995; Goulden at al. 1993). Although it has been shown that $R$ genes function differently when they are transferred to different genetic backgrounds, the situation seems to be different for $R x$, because its expression allows a greater recognition spectrum in Nicotiana spp. compared with potato. Furthermore, our results suggest that the fine specificity of recognition between the $\mathrm{CP}$ and the $R x$ gene product may also be modulated by host factors differing between $R x$-expressing potato and Nicotiana spp.

The second set of experiments presented in this article aimed to determine whether the $R x$ gene product is able to recognize CP other than the PVX, and to see whether $R x$-mediated resistance could control the multiplication of other viruses. This appears to be the case for at least the three Potexviruses evaluated (Fig. 2), in particular for NMV and WClMV, in which systemic invasion was blocked in an $R x$-dependent manner (Figs. 2 and 3). In the case of CymMV, elicitor activity of the CP was demonstrated by both $R x$-dependent HR observed in $\mathrm{CP}$ transient expression experiments and $R x$-dependent in-

Table 1. Presence (+) or absence (-) of a hypersensitive reaction following transient expression through agroinfiltration of the coding sequence of the coat proteins (CPs) or of fragments derived from the CP of different viruses in the leaves of Rx-expressing Nicotiana tabacum

\begin{tabular}{|c|c|c|c|c|c|c|}
\hline \multirow[b]{2}{*}{ Cultures $^{b}$} & \multicolumn{6}{|c|}{ Virus $^{\mathrm{a}}$} \\
\hline & $\mathrm{PVX}_{\mathrm{CP4}}$ & $\mathbf{P V X}_{\mathrm{HB}}$ & WCIMV & NMV & CymMV & HVS \\
\hline $\mathrm{CP}$ & + & - & + & + & + & - \\
\hline $\mathrm{F} 1$ & ND & ND & + & + & - & - \\
\hline $\mathrm{F} 2$ & ND & ND & - & - & - & ND \\
\hline F5 & ND & ND & - & - & - & ND \\
\hline F6 & ND & ND & + & + & - & ND \\
\hline
\end{tabular}

${ }^{\mathrm{a}} \mathrm{PVX}_{\mathrm{CP} 4}$ and $\mathrm{PVX}_{\mathrm{HB}}=$ isolates of Potato virus $\mathrm{X}, \mathrm{WClMV}=$ White clover mosaic virus, $\mathrm{NMV}=$ Narcissus mosaic virus, CymMV $=$ Cymbidium mosaic virus, HVS = Helenium virus $S$, and $\mathrm{ND}=$ not determined.

${ }^{\mathrm{b}} \mathrm{CP}=$ Agrobacterium culture expressing the relevant complete $\mathrm{CP} ; \mathrm{F} 1$ to $\mathrm{F} 6=$ Agrobacterium cultures expressing fragment 1 to 6 of the relevant $\mathrm{CP}$. 
creased symptomatology in the whole-plant assay. However, during these experiments, the fragments of CymMV CP failed to elicit an HR and only the complete CymMV CP was able to elicit an $R x$-dependant HR. The CP of this virus may be a weak elicitor, which could also explain phenotypes observed on the whole plant following inoculation. On the other hand, the CP of the Carlavirus HVS, which is more divergent (Fig. 5), is not able to elicit $R x$-mediated responses. An alignment of $\mathrm{CP}$ sequences indicates that the PVX CP shows 33, 39, and $35 \%$ identity with the CP from NMV, WClMV, and CymMV, respectively, and only $25 \%$ with the CP of HVS (Fig. 5). However, these sequence comparisons do not show an obvious conserved domain of the CP that could represent the $R x$-recognition motif. Indeed, only 40 amino acids are identical between the four Potexvirus CP and these are not particularly clustered. In addition, 26 of them are also present in the $\mathrm{CP}$ sequence of HVS (Fig. 5). An interesting observation, however, is that the four Potexvirus CP have a threonine at position 121 but the HVS CP has a glycine in this position. The other amino acid, important for PVX CP recognition, at position 127, is not conserved between the different Potexviruses, CymMV having an alanine and NMV and WCIMV a methionine in this position. This threonine/methionine combination is also present in the CP of different PVX avirulent strains, including UK3 and DX (Santa Cruz and Baulcombe 1995). Moreover, among the CP sequences of the Flexiviridae family, particularly Potexvirus and Carlavirus, a range of combinations for the two amino acids at position 121 and 127 can be found.

Transient expression of CP fragments from the different viruses (Fig. 6B) confirms, as previously shown for PVX CP, that the $5^{\prime}$ and $3^{\prime}$ extremities of the $\mathrm{CP}$ are not required for the elicitation of the $R x$-mediated resistance. Only 110 amino acids of the PVX CP were known to be necessary to induce $R x$ mediated resistance and to suppress PVX RNA accumulation (Bendahmane et al. 1995; Moffet et al. 2002). Our results suggest that fragments of NMV and WCIMV CP corresponding to the same 110 amino acids are able to induce the $R x$-mediated resistance, as indicated by both the induction of the $R x$-dependent HR (Fig. 4) and the $R x$-dependent increase in conductivity (Fig. 7). Furthermore, the minimal region of these different $\mathrm{CP}$ was reduced by the demonstration that the first 20 amino acids of this fragment are not required for elicitor activity (Fig. 6B). This smaller elicitor of 90 amino acids corresponds to amino acids 50 to 139 of PVX CP containing the key residues 121 and 127. In this region, the $\mathrm{CP}$ of the two Potexviruses (NMV and WCIMV) and of PVX show an average identity of only $40 \%$, indicating a high level of flexibility in the recognition pattern of the $R x$-based sensing machinery. The deletion of the 12 carboxy-terminal amino acids of this minimal elicitor fragment, including the key position 127 (constructs 2 and 5, corresponding to position 50 to 127 and 30 to 127 , respectively, of the PVX CP), abolishes the eliciting activity (Fig. 6B), indicating that the deleted region (from 128 to 139) is required for the elicitor activity. The expression of the short deleted fragment in $R x$-expressing plants could indicate whether this region of 12 amino acids is sufficient to induce an HR; however, this seems unlikely because this fragment does not contain the key residue 121 .

The results reported here show that the product of the $R x$ gene can recognize the $\mathrm{CP}$ of several viruses belonging to the same genus (Table 1), even if these proteins show only a distant relationship in the required region for elicitation. The most likely hypothesis to explain these observations is that the $R x$ molecular sensor targets a conserved structural element of these CP rather than a linear amino acid sequence. The possibility of recognition of a three-dimensional structure has already been raised for the PVX-Rx pathosystem (Chapman et al. 1992; Goulden et al. 1993). Secondary structure predictions of the PVX CP (Baratova et al. 1992a and b) have shown that the key amino acids 121 and 127 are likely to be buried inside the $\mathrm{CP}$ and that their mutation could induce conformational changes of the CP (Querci et al. 1993). A new organization of the PVX CP has recently been proposed by Nemykh and associates (2008) in which a majority of the secondary elements coincide with the model predicted by Baratova and associates (1992a and $b$ ). In this new model, the fraction of predicted $\alpha$ helices $(55 \%)$ is even larger than before. However, it seems that the three-dimensional arrangement of $\alpha$ helices and $\beta$ turns could be quite different from the model predicted before. An experimental analysis of the three-dimensional structure of NMV, WCIMV, CymMV, and PVX CP will provide further information on the nature of a putative conserved structure.

Such a conserved element could be assimilated to a PAMP for plant viruses as has been described for microbes (Brunner et al. 2002; Parker 2003). Penetration of the cell wall exposes the host plasma membrane to microbes, where they encounter extracellular surface receptors that recognize PAMPs. Our most complete understanding of the plant response to PAMPs relates to perception of flagellin, the protein subunit of flagella (Gomez-Gomez and Boller 2000). Flagellin is recognized as a PAMP by many plant species. In Arabidopsis, a 22-amino-acid peptide is sufficient for host receptor activation by FLS2, which is homologous to TLR5 in animal cells (Felix et al. 1999; Gomez-Gomez and Boller 2000; Underhill and Ozinsky 2002). Identification of this potent peptide elicitor facilitated detailed analysis of responses to flagellin using whole-plant and protoplast systems. It may be that multiple PAMP signaling pathways converge and activate defenses via overlapping mitogen-activated protein kinase cascades and transcription factors (Asai et al. 2002). The identification of a minimal elicitor pattern in the $\mathrm{CP}$ of Potexviruses could facilitate the determination of the three-dimensional structure recognized by the $R x$ machinery.

The guard model raises the hypothesis that host proteins will be able to recognize different elicitors and the change in functional properties of the elicitor (Dangl and Jones 2001). Our results support this hypothesis, suggesting that host proteins are able to detect structural or functional differences between different strains of PVX CP as well as CP of different Potexviruses. Recent identification of the GTPase, RanGAP2, as a potential "guardee" of $R x$ or $R x$ homologs (Sacco et al. 2007; Tameling and Baulcombe 2007) is an important stage in the understanding of the $R x$-mediated resistance mechanism, although a direct physical interaction between RanGAP2 and PVX CP has not yet been shown. Further studies are now needed to identify the different partners and the conserved structure of CP implicated in $R x$-mediated resistance in different genetic backgrounds.

\section{MATERIALS AND METHODS}

\section{Plant material.}

Untransformed control plants of $N$. benthamiana, $N$. tabacum cv. Samsun, and transgenic lines expressing the $R x$ gene under its own promoter were used in this study. The $R x$-expressing plants were obtained by Agrobacterium-mediated transformation using the pSLJ9 recombinant plasmid (Bendahmane et al. 1999). Plants were grown in glasshouses under controlled temperature (23 and $19^{\circ} \mathrm{C}$, day and night, respectively) and light (16-h day length).

\section{Mutagenesis of the PVX CP.}

Oligonucleotide-directed mutagenesis (Ho et al. 1989; Horton et al. 1989) was used to introduce specific mutations into the $\mathrm{CP}$ gene of full-length infectious cDNAs clones of $\mathrm{CP}$ of $\mathrm{PVX}_{\mathrm{CP} 4}$. 
The presence of the mutation was confirmed by sequence analysis. The transcripts of these mutant constructs were inoculated first to WT $N$. benthamiana and subsequently to WT and $R x$ expressing transgenic plants.

The mutations introduced in the $\mathrm{CP}$ of $\mathrm{PVX}_{\mathrm{CP} 4}$ changed the codon at position 121 from $\mathrm{ACA}(\mathrm{T})$ to $\mathrm{GTG}(\mathrm{V}), \mathrm{AGC}(\mathrm{S})$, $\mathrm{CCG}(\mathrm{P}), \mathrm{CGG}(\mathrm{R})$, or $\mathrm{AAA}(\mathrm{K})$ and the codon at position 127 from $A A A(K)$ to $C G G(R)$.

\section{Virus isolates and inoculation assays.}

All the viruses used in this study-CymMV, HVS, NMV, PVX strain CP4 (accession number AF172259), PVX strain HB (accession number X72214), and WCIMV-were maintained in WT $N$. benthamiana. To carry out the $R x$-resistance assays, each virus was mechanically inoculated into WT and $R x$-expressing plants. Inoculations were repeated five times on two WT and two $R x$-expressing plants for each virus. Plants were inoculated at the two- to four-leaves stage, with Carborundum (400 mesh) used as abrasive and sap prepared by grinding with sand one leaf of an infected $N$. benthamiana plant in $3 \mathrm{ml}$ of $10 \mathrm{mM}$ phosphate buffer $(\mathrm{pH} \mathrm{7})$, and centrifuging the resulting homogenate for $2 \mathrm{~min}$ at $800 \times g$ before use. The inoculated plants were scored for symptoms of viral infection 21 days after inoculation. The presence of virus was verified by RT-PCR using primers designed to amplify the viral CP (Supplementary Table 1$)$.

\section{RNA isolation.}

Total RNA was extracted from inoculated leaves as previously described (Devic et al. 1989). Specifically, $2 \mathrm{~g}$ of leaf tissue was ground in liquid nitrogen using a mortar and pestle. The powdered material was dispersed in $4 \mathrm{ml}$ of homogenization buffer $(0.1 \mathrm{M} \mathrm{NaCl}, 2 \%$ sodium dodecyl sulfate [SDS], 10 $\mathrm{mM}$ EDTA, and $50 \mathrm{mM}$ Tris- $\mathrm{HCl}, \mathrm{pH} 9.0)$, mixed with $4 \mathrm{ml}$ of phenol/chloroform (1:1), and centrifuged at 3,000 $\times g$ for 20 min. The supernatant was further extracted once with phenol/chloroform. The nucleic acids were precipitated with $5 \mathrm{ml}$ of $100 \%$ ethanol, washed with $70 \%$ ethanol, dried, and resuspended in $150 \mu \mathrm{l}$ of diethylpyrocarbonate (DEPC) water.

\section{DNase treatment.}

Total RNA $(20 \mu \mathrm{g})$ was treated with DNAse I (Promega, Madison, WI, U.S.A.). The reaction mix of $25 \mu \mathrm{l}(7.5 \mathrm{U}$ of DNAse I and $25 \mathrm{U}$ of RNAseOUT) was incubated at $37^{\circ} \mathrm{C}$ for 10 min and completed with $75 \mu \mathrm{l}$ of $\mathrm{H}_{2} \mathrm{O}$. The mix was further extracted once with phenol/chloroform. The nucleic acids were precipitated with $300 \mu \mathrm{l}$ of $100 \%$ ethanol and $15 \mu \mathrm{l}$ of NaAc (3 $\mathrm{M}, \mathrm{pH}$ 5.5), washed with $70 \%$ ethanol, dried, and resuspended in $30 \mu \mathrm{l}$ of DEPC water.

\section{Reverse transcription of the viral CP.}

Total RNA $(2 \mu \mathrm{g})$ was used for first-strand cDNA synthesis, which was primed with 0.02 picomoles of oligonucleotide $(\mathrm{dT})_{20}$ (Invitrogen, Carlsbad, CA, U.S.A.). This first reaction mix of $11.5 \mu \mathrm{l}$ was heated at $70^{\circ} \mathrm{C}$ for $10 \mathrm{~min}$ and then cooled on ice for $5 \mathrm{~min}$. The reaction mix was completed at $20 \mu \mathrm{l}(4 \mu \mathrm{l}$ of $5 \times$ superscript buffer [Invitrogen], $2 \mu \mathrm{l}$ of $100 \mathrm{mM}$ dithiothreitol [DTT], $1 \mu \mathrm{l}$ of $5 \mathrm{mM}$ dNTP, 40 units of RNaseOUT [Invitrogen]) and incubated at $37^{\circ} \mathrm{C}$ for $5 \mathrm{~min}$, after which 100 units of SuperscriptIII (Invitrogen) was added. The reaction was incubated at $37^{\circ} \mathrm{C}$ for $2 \mathrm{~h}$. The first-strand cDNA was converted into double-strand DNA by PCR. These RT-PCR were performed with oligonucleotides using 25 cycles of amplification.

In the same manner, the viral $\mathrm{CP}$ were reverse transcribed from infected or agroinfiltrated tissues. Sequencing before and after propagation in plants was used to test the stability of the viral genome sequence.
Agrobacterium tumefaciens-mediated transient expression of viral CP.

The CP coding sequences from the different viruses were inserted between the $35 \mathrm{~S}$ promoter and terminator in the binary vector pBin61 (Bendahmane et al. 1999). These constructs were transformed into Agrobacterium strain C58C1 carrying the virulence helper plasmid pCH32 (Hamilton et al. 1996). pCH32 expresses VirG and VirE and is used to enhance T-DNA transfer. The binary constructs were transiently expressed in $N$. tabacum leaves as previously described (Bendahmane et al. 2000).

\section{Western blot analysis.}

Inoculated leaves $(500 \mu \mathrm{g})$ were ground in liquid nitrogen and $500 \mu \mathrm{l}$ of $2 \times$ Laemmli solution (10\% glycerol, $3 \%$ SDS, $0.2 \mathrm{M}$ DTT, $0.004 \%$ bromophenol blue, $0.12 \mathrm{M}$ Tris $\mathrm{HCl}, \mathrm{pH}$ 6.8 , in $0.09 \%$ SDS) was added. The samples were boiled at $100^{\circ} \mathrm{C}$ for $10 \mathrm{~min}$ and centrifuged for $10 \mathrm{~min}$ at $10,000 \times \mathrm{g}$. The supernatants were stored at $-20^{\circ} \mathrm{C}$.

Each sample $(20 \mu \mathrm{l})$ was loaded and separated on a $12 \%$ acrylamide gel and blotted on polyvinylidene difluoride (PVDF) membrane (immunoblot PVDF membrane; Biorad, Hercules, CA, U.S.A.) for an hour in transfer buffer (25 mM Tris, $\mathrm{pH} 8.3$; $192 \mathrm{mM}$ glycine; $20 \%$ ethanol). The membrane was washed for 5 min in TTBS (0.1 M Tris; $0.15 \mathrm{M} \mathrm{NaCl}, \mathrm{pH} 7.5$; and $0.1 \%$ Triton X100) and blocked for $1 \mathrm{~h}$ in TTBS $+10 \%$ nonfat milk. The membrane was then washed for $5 \mathrm{~min}$ in TTBS and incubated with the primary antibody (immunoglobulin $\mathrm{G}[\mathrm{IgG}]$ polyclonal antibody against PVX; DSMZ, Braunschweig, Germany) at $1 / 500$ dilution overnight at $4^{\circ} \mathrm{C}$. The membrane was then washed three times for $5 \mathrm{~min}$ in TTBS and incubated through the day with secondary antibody (goat anti rabbit IgG linked to alkaline phosphatase; DSMZ) at 1/1,000 dilution. After four washes of $10 \mathrm{~min}$ in TTBS, the membrane was developed using the AP kit (AP conjugate substrate kit; Biorad).

Molecular markers used were low prestained markers (Precision plus Protein all blue standard, Biorad; Page ruler protein ladder, Fermentas, Vilnius, Lithuania).

\section{Electrolyte leakage assays.}

These measurements were performed as previously described (Farnham and Baulcombe 2006). Four 7-mm-diameter leaf disks from the same Agrobacterium-infiltrated leaf were collected at 24,48 , or $72 \mathrm{~h}$ after infiltration and placed in a $1.5-\mathrm{ml}$ tube before adding $1 \mathrm{ml}$ of analytical grade $\mathrm{H}_{2} \mathrm{O}$. Samples were incubated for $10 \mathrm{~min}$ at $37^{\circ} \mathrm{C}$ at a pressure of 1 Pascal. Leaf disks were then incubated at room temperature for $30 \mathrm{~min}$, removed from the tubes, and stored at $-20^{\circ} \mathrm{C}$. Conductivity was measured using a Horiba B-173 conductivity meter. Electrolyte solutions were thawed at room temperature and $0.8 \mathrm{ml}$ of the solution was added to $3.2 \mathrm{ml}$ of analytical grade $\mathrm{H}_{2} \mathrm{O}$ in a $15-\mathrm{ml}$ tube. For each data point, five independent replicates were analyzed. Results are shown as the mean \pm standard deviation.

\section{ACKNOWLEDGMENTS}

We thank M. Caboche and D. Baulcombe for critical review of the manuscript; S. Winter (DSMZ, Braunschweig, Germany) for providing the Carla- and Potexviruses used in this study; and P. Grillot and P. Audigier for the culture of the different Nicotiana lines. I. Baurès was supported by a grant from French ministry of research and higher education.

\section{LITERATURE CITED}

Aravind, L., Iyer, L. M., Leipe, D. D., and Koonin, E. V. 2004. A novel family of P-loop NTPases with an unusual phyletic distribution and transmembrane segments inserted within the NTPase domain. Genome Biol. 5:R30. 
Asai, T., Tena, G., Plotnikova, J., Willmann, M. R., Chiu, W. L., GomezGomez, L., Boller, T., Ausubel, F. M., and Sheen, J. 2002. MAP kinase signalling cascade in Arabidopsis innate immunity. Nature 415:977-983.

Baratova, L. A., Grebenshchikov, N. I., Dobrov, E. N., Gedrovich, A. V., Kashirin, I. A., Shishkov, A. V., Efimov, A. V., Jarvekulg, L., Radavsky, Y. L., and Saarma, M. 1992a. The organization of potato virus X coat proteins in virus particles studied by tritium planigraphy and model building. Virology 188:175-180.

Baratova, L. A., Grebenshchikov, N. I., Shishkov, A. V., Kashirin, I. A., Radavsky, J. L., Jarvekulg, L., and Saarma, M. 1992b. The topography of the surface of potato virus X: Tritium planigraphy and immunological analysis. J. Gen. Virol. 73 (Pt. 2):229-235.

Belkhadir, Y., Nimchuk, Z., Hubert, D. A., Mackey, D., and Dangl, J. L. 2004. Arabidopsis RIN4 negatively regulates disease resistance mediated by RPS 2 and RPM1 downstream or independent of the NDR 1 signal modulator and is not required for the virulence functions of bacterial type III effectors AvrRpt2 or AvrRpm1. Plant Cell 16:2822-35.

Bendahmane, A., Kohm, B. A., Dedi, C., and Baulcombe, D. C. 1995. The coat protein of potato virus $\mathrm{X}$ is a strain-specific elicitor of Rx1-mediated virus resistance in potato. Plant J. 8:933-941.

Bendahmane, A., Kanyuka, K., and Baulcombe, D. C. 1999. The $R x$ gene from potato controls separate virus resistance and cell death responses. Plant Cell 11:781-792.

Bendahmane, A., Querci, M., Kanyuka, K., and Baulcombe, D. C. 2000. Agrobacterium transient expression system as a tool for the isolation of disease resistance genes: Application to the $\mathrm{Rx} 2$ locus in potato. Plant $\mathrm{J}$. 21:73-81.

Bittner-Eddy, P. D., Crute, I. R., Holub, E. B., and Beynon, J. L. 2000. RPP13 is a simple locus in Arabidopsis thaliana for alleles that specify downy mildew resistance to different avirulence determinants in Peronospora parasitica. Plant J. 21:177-188.

Botella, M. A., Parker, J. E., Frost, L. N., Bittner-Eddy, P. D., Beynon, J. L., Daniels, M. J., Holub, E. B., and Jones, J. D. 1998. Three genes of the Arabidopsis RPP1 complex resistance locus recognize distinct Peronospora parasitica avirulence determinants. Plant Cell 10:1847-1860.

Brunner, F., Rosahl, S., Lee, J., Rudd, J., Geiler, C., Kauppinen, S., Rasmussen, G., Scheel, D., and Nurnberger, T. 2002. Pep-13, a plant defense-inducing pathogen-associated pattern from Phytophthora transglutaminases. EMBO (Eur. Mol. Biol. Organ.) J. 21:6681-6688.

Cadle-Davidson, M. M., and Jahn, M. M. 2005. Resistance conferred against Bean common mosaic virus by the incompletely dominant I locus of Phaseolus vulgaris is active at the single cell level. Arch. Virol. 150:2601-2608

Chapman, S., Hills, G., Watts, J., and Baulcombe, D. 1992. Mutational analysis of the coat protein gene of potato virus X: Effects on virion morphology and viral pathogenicity. Virology 191:223-230.

Cockerham, G. 1970. Genetical studies on resistance to Potato virus X and Y. Heredity 25:309-348.

Collmer, C. W., Marston, M. F., Taylor, J. C., and Jahn, M. 2000. The I gene of bean: A dosage-dependent allele conferring extreme resistance, hypersensitive resistance, or spreading vascular necrosis in response to the potyvirus Bean common mosaic virus. Mol. Plant-Microbe Interact. 13:1266-1270.

Dangl, J. L., and Jones, J. D. 2001. Plant pathogens and integrated defence responses to infection. Nature 411:826-833.

Devic, M., Jaegle, M., and Baulcombe, D. 1989. Symptom production on tobacco and tomato is determined by two distinct domains of the satellite RNA of cucumber mosaic virus (strain Y). J. Gen. Virol. 70 (Pt 10):2765-2774.

DeYoung, B. J. and Innes, R. W. 2006. Plant NBS-LRR proteins in pathogen sensing and host defense. Nat. Immunol. 7:1243-9.

Ellis, J., Dodds, P., and Pryor, T. 2000. Structure, function and evolution of plant disease resistance genes. Curr. Opin. Plant Biol. 3:278-284.

Farnham, G., and Baulcombe, D. C. 2006. Artificial evolution extends the spectrum of viruses that are targeted by a disease-resistance gene from potato. Proc. Natl. Acad. Sci. U.S.A. 103:18828-18833.

Felix, G., Duran, J. D., Volko, S., and Boller, T. 1999. Plants have a sensitive perception system for the most conserved domain of bacterial flagellin. Plant J. 18:265-276.

Flor, H. H. 1971. Current status of the gene-for-gene concept. Annu. Rev. Phytopathol. 9:275-296.

Fraser, R. S. S., and Loughlin, S. A. R. 1980. Resistance to tobacco mosaic virus in tomato: Effects of the Tm-1 gene on virus multiplication. J. Gen. Virol. 48:87-96.

Fujita, Y., Fujita, M., Mise, K., Kobori, T., Osaki, T., and Furusawa, I. 2000. Bromovirus movement protein conditions for the host specificity of virus movement through the vascular system and affects pathogenicity in cowpea. Mol. Plant-Microbe Interact. 13:1195-1203.

Gomez-Gomez, L., and Boller, T. 2000. FLS2: An LRR receptor-like kinase involved in the perception of the bacterial elicitor flagellin in
Arabidopsis. Mol. Cell 5:1003-1011.

Goulden, M. G., and Baulcombe, D. C. 1993. Functionally homologous host components recognize potato virus $\mathrm{X}$ in Gomphrena globosa and potato. Plant Cell 5:921-930.

Goulden, M. G., Kohm, B. A., Cruz, S. S., Kavanagh, T. A., and Baulcombe, D. C. 1993. A feature of the coat protein of potato virus X affects both induced virus resistance in potato and viral fitness. Virology 197:293302.

Hajimorad, M. R., and Hill, J. H. 2001. Rsv1-mediated resistance against Soybean mosaic virus- $\mathrm{N}$ is hypersensitive response-independent at inoculation site, but has the potential to initiate a hypersensitive responselike mechanism. Mol. Plant-Microbe Interact. 14:587-598.

Hamilton, C. M., Frary, A., Lewis, C., and Tanksley, S. D. 1996. Stable transfer of intact high molecular weight DNA into plant chromosomes. Proc. Natl. Acad. Sci. U.S.A. 93:9975-9979.

Heath, M. C. 2000. Hypersensitive response-related death. Plant Mol. Biol. 44:321-334

Ho, S. N., Hunt, H. D., Horton, R. M., Pullen, J. K., and Pease, L. R. 1989. Site-directed mutagenesis by overlap extension using the polymerase chain reaction. Gene 77:51-59.

Horton, R. M., Hunt, H. D., Ho, S. N., Pullen, J. K., and Pease, L. R. 1989. Engineering hybrid genes without the use of restriction enzymes: Gene splicing by overlap extension. Gene 77:61-68.

Huisman, M. J., Linthorst, H. J., Bol, J. F., and Cornelissen, J. C. 1988. The complete nucleotide sequence of potato virus $\mathrm{X}$ and its homologies at the amino acid level with various plus-stranded RNA viruses. J. Gen Virol. 69 (Pt. 8):1789-1798.

Jones, J. D. and Dangl, J. L. 2006. The plant immune system. Nature 444:323-9.

Jones, D. A., and Jones, J. D. G. 1997. The role of leucine-rich repeat proteins in plant defences. Adv. Bot. Res. 24:89-167.

Kavanagh, T., Goulden, M., Santa Cruz, S., Chapman, S., Barker, I., and Baulcombe, D. 1992. Molecular analysis of a resistance-breaking strain of potato virus X. Virology 189:609-617.

Kohm, B. A., Goulden, M. G., Gilbert, J. E., Kavanagh, T. A., and Baulcombe, D. C. 1993. A potato virus X resistance gene mediates an induced, nonspecific resistance in protoplasts. Plant Cell 5:913-920.

Lee, L., Palukaitis, P., and Gray, S. M. 2002. Host-dependent requirement for the Potato leafroll virus $17-\mathrm{kDa}$ protein in virus movement. Mol. Plant-Microbe Interact. 15:1086-1094.

Leipe, D. D., Koonin, E. V., and Aravind, L. 2004. STAND, a class of P-loop NTPases including animal and plant regulators of programmed cell death: Multiple, complex domain architectures, unusual phyletic patterns, and evolution by horizontal gene transfer. J. Mol. Biol. 343:1-28.

Martin, G. B., Bogdanove, A. J., and Sessa, G. 2003. Understanding the functions of plant disease resistance proteins. Annu. Rev. Plant Biol. 54:23-61.

McDowell, J. M., Dhandaydham, M., Long, T. A., Aarts, M. G., Goff, S., Holub, E. B., and Dangl, J. L. 1998. Intragenic recombination and diversifying selection contribute to the evolution of downy mildew resistance at the RPP8 locus of Arabidopsis. Plant Cell 10:1861-1874.

Meyers, B. C., Chin, D. B., Shen, K. A., Sivaramakrishnan, S., Lavelle, D. O., Zhang, Z., and Michelmore, R. W. 1998. The major resistance gene cluster in lettuce is highly duplicated and spans several megabases. Plant Cell 10:1817-1832.

Moffett, P., Farnham, G., Peart, J., and Baulcombe, D. C. 2002. Interaction between domains of a plant NBS-LRR protein in disease resistancerelated cell death. EMBO (Eur. Mol. Biol. Organ.) J. 21:4511-4519.

Moreira, A., Jones, R. A. C., and Fribourg, C. E. 1980. Properties of a resistance-breaking strain of potato virus X. Ann. Appl. Biol. 95:93-103.

Motoyoshi, F., and Oshima, N. 1977. Expression of genetically controlled resistance to tobacco mosaic virus infection in isolated tomato leaf mesophyll protoplasts. J. Gen. Virol. 34:499-506.

Nemykh, M. A., Efimov, A. V., Novikov, V. K., Orlov, V. N., Arutyunyan, A. M., Drachev, V. A., Lukashina, E. V., Baratova, L. A., and Dobrov, E. N. 2008. One more probable structural transition in potato virus $\mathrm{X}$ virions and a revised model of the virus coat protein structure. Virology 373:61-71.

Noel, L., Moores, T. L., van Der Biezen, E. A., Parniske, M., Daniels, M. J., Parker, J. E., and Jones, J. D. 1999. Pronounced intraspecific haplotype divergence at the RPP5 complex disease resistance locus of Arabidopsis. Plant Cell 11:2099-2112.

Nurnberger, T., Brunner, F., Kemmerling, B., and Piater, L. 2004. Innate immunity in plants and animals: Striking similarities and obvious differences. Immunol. Rev. 198:249-66.

Orman, B. E., Celnik, R. M., Mandel, A. M., Torres, H. N., and Mentaberry, A. N. 1990. Complete cDNA sequence of a South American isolate of potato virus X. Virus Res. 16:293-305.

Parker, J. E. 2003. Plant recognition of microbial patterns. Trends Plant Sci. 8:245-247 
Querci, M., van der Vlugt, R., Goldbach, R., and Salazar, L. F. 1993. RNA sequence of Potato virus X strain HB. J. Gen. Virol. 74 (Pt. 10):22512255.

Sacco, M. A., Mansoor, S., and Moffett, P. 2007. A RanGAP protein physically interacts with the NB-LRR protein $\mathrm{Rx}$, and is required for Rx-mediated viral resistance. Plant J. 52:82-93.

Santa Cruz, S., and Baulcombe, D. 1995. Analysis of potato virus X coat protein genes in relation to resistance conferred by the genes $N x, N b$ and Rxl of potato. J. Gen. Virol. 76 (Pt. 8):2057-2061.

Shirasu, K., and Schulze-Lefert, P. 2000. Regulators of cell death in disease resistance. Plant Mol. Biol. 44:371-385.

Skryabin, K. G., Kraev, A. S., Morozov, S., Rozanov, M. N., Chernov, B. K., Lukasheva, L. I., and Atabekov, J. G. 1988. The nucleotide sequence of potato virus X RNA. Nucleic Acids Res. 16:10929-10930.

Spetz, C., and Valkonen, J. P. 2004. Potyviral 6K2 protein long-distance movement and symptom-induction functions are independent and hostspecific. Mol. Plant-Microbe Interact. 17:502-510.

Staskawicz, B. J., Ausubel, F. M., Baker, B. J., Ellis, J. G., and Jones, J. D. 1995. Molecular genetics of plant disease resistance. Science 268:661667.

Takken, F. L., Albrecht, M., and Tameling, W. I. 2006. Resistance proteins: Molecular switches of plant defence. Curr. Opin. Plant Biol. 9:383-90.

Tameling, W. I. L., and Baulcombe, D. C. 2007. Physical association of the NB-LRR resistance protein Rx with a Ran GTPase-activating protein is required for extreme resistance to Potato virus X. Plant Cell 19:1682-1694.
Tameling, W. I., Elzinga, S. D., Darmin, P. S., Vossen, J. H., Takken, F. L Haring, M. A., and Cornelissen, B. J. 2002. The tomato $R$ gene products I-2 and MI-1 are functional ATP binding proteins with ATPase activity. Plant Cell 14:2929-2939.

Tameling, W. I., Vossen, J. H., Albrecht, M., Lengauer, T., Berden, J. A., Haring, M. A., Cornelissen, B. J., and Takken, F. L. 2006. Mutations in the NB-ARC domain of I-2 that impair ATP hydrolysis cause autoactivation. Plant Physiol. 140:1233-1245.

Tozzini, A. C., Ceriani, M. F., Saladrigas, M. V., and Hopp, H. E. 1991. Extreme resistance to infection by potato virus $\mathrm{X}$ in genotypes of wild tuber-bearing Solanum species. Potato Res. 34:317-324.

Ueda, H., Yamaguchi, Y., and Sano, H. 2006. Direct interaction between the tobacco mosaic virus helicase domain and the ATP-bound resistance protein, $\mathrm{N}$ factor during the hypersensitive response in tobacco plants. Plant Mol. Biol. 61:31-45.

Underhill, D. M., and Ozinsky, A. 2002. Toll-like receptors: Key mediators of microbe detection. Curr. Opin. Immunol. 14:103-110.

Van der Biezen, E. A., and Jones, J. D. 1998. The NB-ARC domain: A novel signalling motif shared by plant resistance gene products and regulators of cell death in animals. Curr. Biol. 8:R226-227.

Wang, H. L., Wang, Y., Giesman-Cookmeyer, D., Lommel, S. A., and Lucas, W. J. 1998. Mutations in viral movement protein alter systemic infection and identify an intercellular barrier to entry into the phloem long-distance transport system. Virology 245:75-89.

Young, N. D. 2000. The genetic architecture of resistance. Curr. Opin Plant Biol. 3:285-290. 